\title{
Survival of Unstressed and Acid-, Cold-, and Starvation-Stress-Adapted Listeria monocytogenes in Ham Extract with Hops Beta Acids and Consumer Acceptability of HBA on Ready-to-Eat Ham
}

\author{
Li Wang ${ }^{1}$ and Cangliang Shen ${ }^{2}$ \\ ${ }^{1}$ State Key Laboratory of Food Science and Technology, National Engineering Laboratory for Cereal Fermentation Technology, \\ School of Food Science and Technology, Jiangnan University, Wuxi, Jiangsu 214122, China \\ ${ }^{2}$ Division of Animal and Nutritional Sciences, West Virginia University, Morgantown, WV 26506, USA \\ Correspondence should be addressed to Cangliang Shen; cangliang.shen@mail.wvu.edu
}

Received 4 December 2014; Revised 11 February 2015; Accepted 16 February 2015

Academic Editor: Avelino Alvarez-Ordóñez

Copyright (C) 2015 L. Wang and C. Shen. This is an open access article distributed under the Creative Commons Attribution License, which permits unrestricted use, distribution, and reproduction in any medium, provided the original work is properly cited.

\begin{abstract}
The efficacy of hops beta acids (HBA) against unstressed and stress-adapted Listeria monocytogenes in ham extract and the consumers' acceptability of HBA on ready-to-eat (RTE) hams were investigated. Unstressed or acid-, cold-, or starvation-stress-adapted L. monocytogenes was inoculated (1.3-1.5 $\log \mathrm{CFU} / \mathrm{mL})$ into $10 \%$ ham extract, without (control) or with HBA $(4.44 \mathrm{or} 10.0 \mu \mathrm{g} / \mathrm{mL})$. Survival/growth of the pathogen during storage $\left(7.2^{\circ} \mathrm{C}, 26\right.$ days) was monitored periodically. Sensory evaluation ( 30 participants, 9-point hedonic scale) was performed with hams dipped into $0.05,0.11$, and $0.23 \%$ HBA solution. Ham extracts without HBA supported rapid growth of unstressed and stress-adapted cells with growth rates of $0.39-0.71 \log \mathrm{CFU} / \mathrm{mL} / \mathrm{day}$ and lag phases of $0-3.26$ days. HBA inhibited growth of unstressed L. monocytogenes by slowing $(P<0.05)$ growth rate $(0.24-0.29 \log C F U / \mathrm{mL} / \mathrm{day})$ and increasing $(P<0.05)$ length of the lag phase (3.49-12.98 days) compared to control. Acid-, cold-, or starvation-stress-adapted cells showed cross protection against HBA with greater $(P<0.05)$ growth rates $(0.44-0.66 \log \mathrm{CFU} / \mathrm{mL} /$ day $)$ and similar or shorter lag phases (0-5.44 days) than unstressed cells. HBA did not $(P>0.05)$ affect sensory attributes of RTE ham. These results are useful for RTE meat processors to develop operational protocols using HBA to control L. monocytogenes.
\end{abstract}

\section{Introduction}

Listeria monocytogenes, a Gram-positive, non-endosporeforming, facultative, and psychrotrophic foodborne pathogen, causes listeriosis, which is an important public health problem in the United States [1]. The groups with high risk to listeriosis include older adults, pregnant women, newborn babies, and immune-compromised patients [2]. The "zerotolerance" policy was established by the U.S. Department of Agriculture Food Safety and Inspection Service (USDAFSIS) in early 1990s for guidance and standards of testing and control of L. monocytogenes in ready-to-eat (RTE) meat products [3]. However, from 1998 to 2002, several multistate outbreaks of listeriosis associated with RTE deli meat products occurred in the United States [4-7]. Immediately after these outbreaks, in 2003, the USDA-FSIS began to require RTE meat processors to execute "three alternatives" for $L$. monocytogenes control. Alternatives 1 and 2 require the use of postlethality treatments including the application of antimicrobials [8]. However, since then, the detected presence of L. monocytogenes in RTE meat and poultry products has decreased gradually. Contamination of L. monocytogenes in deli meat still costs approximately $\$ 1.1$ billion and 4,000 deaths each year in USA [9]. Therefore, processors of RTE products should continue to develop effective approaches for control of Listeria during RTE meat processing [9].

Various stresses adapted cells often develop and survive in the meat processing environment or on meat surfaces. For instance, increasing use of acid treatments, such as lactic or acetic acids, on beef or poultry carcasses induced 
the development of acid-stress-adapted pathogenic cells. Similarly, low temperature food storage may lead to coldstress-resistant cells; exposure of cells to poor nutrition areas such as facility surfaces, walls, and floors may induce starvation-stressed cells [10]. The efficacy of antimicrobials is sometimes decreased due to the generation of cross protection when a stress-adapted cell is subsequently exposed to a sequentially sublethal stress [11]. Therefore, the stress response of foodborne pathogens in different food systems has recently received much research attention.

Hops beta acids (HBA), extracted from hops flowers, with primary components of lupulone $\left(\mathrm{C}_{27} \mathrm{H}_{38} \mathrm{O}_{4}\right)$, colupulone $\left(\mathrm{C}_{26} \mathrm{H}_{37} \mathrm{O}_{4}\right)$, and adlupulone $\left(\mathrm{C}_{27} \mathrm{H}_{38} \mathrm{O}_{4}\right)$ have been approved by the USDA-FSIS and US-Food and Drug Administration to be used as generally recognized as safe (GRAS) antimicrobial agents on cooked meat surfaces and in casings [12, 13]. Previous studies by Shen and Sofos showed that HBA can efficiently inhibit growth of $L$. monocytogenes in a culture broth medium [14] and on frankfurters under vacuum packaged storage [15]. However, no published literature addressed the antilisterial activity of HBA in food systems, particularly with various stresses adapted $L$. monocytogenes. In addition, hops have been well known for a special dark brownish color and bitter taste that contribute to the beer brewing process, and no published studies evaluated consumer acceptability of application of HBA on RTE meat products.

Therefore, the objectives of this study were to evaluate the efficacy of HBA to inactivate unstressed and acid-, cold-, and starvation-stress-adapted $L$. monocytogenes in ham extract during storage at $7.2^{\circ} \mathrm{C}$ and the sensory acceptability of HBA applied on commercial RTE hams.

\section{Materials and Methods}

2.1. Bacterial Strains and Preparation of Unstressed or StressAdapted Cells. The 4-strain mixture of L. monocytogenes (kindly provided by Dr. Joshua Gurlter, at USDA-ARS, Wyndmoor, PA) used in this study included ATCC 15213, Scott A 724 (Massachusetts meat outbreak, serotype 4b), L499 (sliced turkey outbreak strain, human isolate, serotype $1 / 2 \mathrm{a}$ ), and L502 (chocolate milk outbreak, serotype $1 / 2 \mathrm{~b}$ ). Each L. monocytogenes strain, taken from the $-20^{\circ} \mathrm{C}$ stock culture, was first activated by streak plating onto PALCAM agar (Difco, BD, Sparks, MD) and then incubated at $35^{\circ} \mathrm{C}$ for $48 \mathrm{~h}$. The procedure of preparing unstressed and three types of stress-adapted cells followed the previous study [16]. To prepare the unstressed cells, a single colony of each $L$. monocytogenes strain was cultured and subcultured $\left(35^{\circ} \mathrm{C}\right.$, $24 \mathrm{~h}$ ) in $10 \mathrm{~mL}$ of glucose-free tryptic soy broth with yeast extract (TSB-G + YE). To prepare the acid-stress-adapted cells, the TSB-G + YE cultured $\left(35^{\circ} \mathrm{C}, 24 \mathrm{~h}\right)$ cell suspension was subcultured $\left(0.1 \mathrm{~mL}, 24 \mathrm{~h}\right.$ at $\left.35^{\circ} \mathrm{C}\right)$ into $10 \mathrm{~mL}$ of TSB-G + YE supplemented with $1 \%$ glucose. For preparation of coldand starvation-stress-adapted cells, the TSB-G + YE cultured $\left(35^{\circ} \mathrm{C}, 24 \mathrm{~h}\right)$ cell suspension was first triplicate-washed in $10 \mathrm{~mL}$ phosphate-buffered saline (PBS, pH 7.4), resuspended in $10 \mathrm{~mL}$ of TSB-G + YE with storage at $4^{\circ} \mathrm{C}$ for 7 days, and resuspended in $10 \mathrm{~mL}$ of $0.85 \% \mathrm{NaCl}$ solution with storage at $35^{\circ} \mathrm{C}$ for 48 hours, respectively. Prior to the experiment, the unstressed or acid-, cold-, or starvation-stress-adapted cells of each strain were washed by centrifuging at $4,629 \times \mathrm{g}$ for $15 \mathrm{~min}$ at $4^{\circ} \mathrm{C}$ three times with $10 \mathrm{~mL}$ PBS. The cell pellets were resuspended and serially diluted in PBS to reach a target inoculation level of 1.3 to $1.6 \log \mathrm{CFU} / \mathrm{mL}$ when $0.1 \mathrm{~mL}$ of inoculum was added into ham extract solutions.

2.2. Ham Extract Preparation and Inoculation. Fresh uncured ham was purchased from a local supermarket at Wuxi, Jiangsu, China, and manually cut into $7 \times 8 \mathrm{~cm}^{2}$ pieces. The $10 \%(\mathrm{w} / \mathrm{w})$ ham extract was prepared by placing the cut ham pieces into distilled water (1:10 by volume), homogenized for $2 \mathrm{~min}$ in a masticator (IUL Instruments, Barcelona, Spain), and then passed through 2 layers of cheese cloth. The homogenate was autoclaved to sterilize natural bacterial flora and cooled to room temperature before aseptically dispensing $100 \mathrm{~mL}$ into sterile glass bottles. HBA solution (45\% product, brownish purple color, water soluble, density: $1.07 \pm 0.01 \mathrm{~g} / \mathrm{mL}$ ), kindly provided by S.S. Steiner Inc. at New York, NY, was dissolved in distilled water and added to the aforementioned sterile ham extract in appropriate amounts to reach concentrations of $0,4.44$ and $10 \mathrm{mg} / \mathrm{L}$. As previously indicated, the $100 \mathrm{~mL}$ of ham extract solutions was inoculated with $0.1 \mathrm{~mL}$ of the diluted inoculum. The inoculated glass bottles were then stored at a refrigerated incubator set at $7.2^{\circ} \mathrm{C}$ (Fisher Scientific, Fair Lawn, NY, stability $\pm 0.2^{\circ} \mathrm{C}$ ) for up to 26 days.

2.3. Microbiological and $p H$ Analyses. On days $0,3,6$, $9,12,16,20$, and 26 during storage, an aliquot of $5 \mathrm{~mL}$ solution for each treatment was 10 -fold serially diluted in $0.1 \%$ peptone water and surface plated onto tryptic soy agar (Difco, Becton Dickinson), supplemented with $0.6 \%$ yeast extract (Acumedia, Lansing, MI; TSAYE) and PALCAM agar for enumeration of L. monocytogenes in a support medium and a selective medium, respectively. Colonies were counted manually after incubation at $30^{\circ} \mathrm{C}$ for $48 \mathrm{~h}$ with a detection limit of $0.5 \log \mathrm{CFU} / \mathrm{mL}$. Following microbial analysis, the $\mathrm{pH}$ of the homogenate was measured using a digital $\mathrm{pH}$ meter (Fisher Scientific, Fair Lawn, NY).

2.4. Sensory Evaluation. Sensory analysis was performed by evaluating consumer acceptability of unheated, fresh purchased RTE ham after dipping into HBA solutions. The fresh purchased ham was sliced in a Hobart $271212^{\prime \prime}$ semiautomatic slicer (Hobart Mfg. Co., Troy, $\mathrm{OH}$ ) and manually cut into pieces of $7 \mathrm{~cm} \times 8 \mathrm{~cm}$ per side with total surface area of $112 \mathrm{~cm}^{2}$. The ham slices were left untreated (control) or were immersed in 0 (distilled water), 0.05, 0.11, and 0.23\% HBA solutions to reach the residual HBA concentrations of $0,2.0$, 4.44 , and $10 \mathrm{mg} / \mathrm{kg}$ on the product surface. The dipping treatment was applied by immersing 20 pieces of ham in $250 \mathrm{~mL}$ of prepared HBA solution for $2 \mathrm{~min}$, followed by draining for $1 \mathrm{~min}$, vacuum packaging (A300/16, Multivac Inc., Germany), and overnight storage at $4^{\circ} \mathrm{C}$. To verify absorption of HBA on the surface of ham $(\mathrm{mg} / \mathrm{kg})$, preliminary experiments were conducted to determine the weight gained by each ham 
piece after 2 min of dipping into distilled water followed by draining for $1 \mathrm{~min}$ as described in the previous study [15].

The sensory evaluation tests were approved by the Jiang Nan University Institutional Review Board (IRB) and were conducted in a state-of-the-art sensory laboratory. A random coded three-digit number was assigned to each sample to identify treatment groups. An untrained panel of 30 consumers was recruited from the School of Food Science and Technology at Jiang Nan University (Wuxi, Jiangsu, China) to evaluate hams for appearance, color, odor, flavor, texture, and overall acceptability. Room temperature water in plastic cups and fresh unsalted crackers were provided to each panel member to clean their palates well between samples. A 9point hedonic scale, where 1 indicates dislike extremely and 9 indicates like extremely, was used to evaluate the appearance, odor, flavor, and overall acceptability of hams. The color (1 indicating extremely pale and 9 indicating extremely dark) and texture (1 indicating extremely soft and 9 indicating extremely firm) of hams were also evaluated.

2.5. Statistical Analysis and Data Modeling. The experiment was performed twice, and for each replication three individual samples were analyzed at each sampling time $(n=6)$. The $\mathrm{pH}$ and microbiological data (converted to $\log \mathrm{CFU} / \mathrm{mL}$ ) were analyzed using the Mixed Model Procedure of SAS with independent variables including type of stress, treatment, time, and interactions between two and three independent factors. Results of sensory evaluation were analyzed using One-Way ANOVA of SAS. Means and standard deviations were calculated, and the differences among subgroup means were separated using a LSD adjustment for multiple comparison at the significance level of $\alpha=0.05$. USDAIntegrated-Predictive-Modeling-Program (IPMP) [17] and DMFIT software (Institute of Food Research, Reading, UK) were used to estimate parameters of the pathogen cells' survival/growth curve during storage. For each model, the six repeats of experimental data were used to estimate, through the root mean square error (RMSE) and Akaike Information Criterion (AIC), how well the model predicted the data.

\section{Results and Discussion}

3.1. Survival/Growth of Unstressed or Stress-Adapted L. monocytogenes in Ham Extract after Exposure to HBA. Recently, the U.S. National Advisory Committee on Microbial Criteria for Foods suggested that the evaluation of antimicrobial agents inhibiting L. monocytogenes growth on RTE meat products should include a temperature of $45^{\circ} \mathrm{F}\left(7.2^{\circ} \mathrm{C}\right)$, which reflects the real RTE meat processing environment [9]. In this study, the growth behavior of unstressed or acid-, cold-, or starvation-stress-adapted L. monocytogenes in ham extract containing 4.44 or $10.0 \mathrm{mg} / \mathrm{L}$ of HBA was evaluated during storage at $7.2 \pm 0.2^{\circ} \mathrm{C}$. Throughout the 26 days of storage, the L. monocytogenes populations for all treatments on TSAYE (Figure 1) did not differ $(P>0.05)$ from those observed on PALCAM agar (Figure 2), indicating that the majority of $L$. monocytogenes can recover and grow on selective agar and HBA did not cause injury of the pathogen cells [18].
Therefore, the L. monocytogenes populations derived from the PALCAM agar were used to describe the growth dynamics of all treatments.

The initial unstressed and acid-, cold-, and starvationstressed L. monocytogenes populations were 1.7, 1.5, 1.7, and $1.3 \log \mathrm{CFU} / \mathrm{mL}$, respectively. As expected, the unstressed and 3 types of stress-adapted pathogen cells grew rapidly and reached 7.8 to $8.7 \log \mathrm{CFU} / \mathrm{mL}$ by the end of storage (Figure 2). At day 26, the final population of acid-, cold- and starvation-stressed cells averaged $0.8 \log \mathrm{CFU} / \mathrm{mL}$ greater $(P<0.05)$ than that of the unstressed cells (Figure 2$)$.

After exposure to HBA, the survival/growth behavior of unstressed and 3 types of stress-adapted cells was different $(P<0.05)$. For unstressed pathogenic cells, no immediate reduction was observed in 4.44 and $10 \mathrm{mg} / \mathrm{L}$ HBA solutions (Figure 2), which agrees with previous studies by Shen and Sofos [14], who reported that the initial amounts of $L$. monocytogenes in all treatments with or without HBA ranged from 2.6 to $2.8 \log \mathrm{CFU} / \mathrm{mL}$. During storage at $7.2^{\circ} \mathrm{C}$, the unstressed L. monocytogenes growth was inhibited by HBA and this inhibition increased with increasing concentrations of HBA, which is in agreement with previous studies by Shen and Sofos [14] and Shen et al. [15]. The inhibition continued for up to 6 days and 12 days for 4.44 and $10 \mathrm{mg} / \mathrm{L}$ of $\mathrm{HBA}$, resulting in $0.6(P>0.05,4.44 \mathrm{mg} / \mathrm{L}$ of HBA) and $3.3 \log \mathrm{CFU} / \mathrm{mL}(P<0.05,10.0 \mathrm{mg} / \mathrm{L}$ of $\mathrm{HBA})$ lower pathogen populations compared to the control by the end of 26-day storage (Figure 2). The mode-of-action of HBA for the inhibition of $L$. monocytogenes growth is attributed mainly to the leakage of the cytoplasmic contents, the release of protons with a proton motive force depletion, the drop of intracellular $\mathrm{pH}$, and the inhibition of the active transport of sugar and amino acids [19].

In general, after exposure to 4.44 or $10.0 \mathrm{mg} / \mathrm{L}$ of $\mathrm{HBA}$, the acid-, cold- and starvation-stress-adapted L. monocytogenes cells showed fast growth and high final pathogen populations, ranging from 8.3 to $8.4,8.5$ to 8.8 , and 8.6 to 8.9, respectively (Figure 2). Among the three types of stressadapted cells, the growth curves of $4.44 \mathrm{mg} / \mathrm{L} \mathrm{HBA-treated}$ samples were very similar to the control (Figure 2), which shows an apparent loss of inhibitory activity of $4.44 \mathrm{mg} / \mathrm{L}$ HBA to various stressed cells. During storage, a lower $(P<$ $0.05)$ pathogen growth was noticed in $10.0 \mathrm{mg} / \mathrm{L}$ HBA-treated samples than in those from the control, particularly for coldand starvation-stressed cells. However, this inhibition was much lower $(P<0.05)$ than that observed in unstressed cells. Therefore, a cross protection effect obviously developed among acid-, cold- or starvation-stress-adapted cells when exposed to HBA.

The strategies used by microorganisms to resist acid stress include $\mathrm{pH}$ homeostasis, changes in membrane structure by alteration of protein permeability, internal buffering ability, and the $\mathrm{pH}$ stability of essential proteins [20]. To survive in a cold-stress environment, bacterial cells usually modify the cell membrane to maintain membrane fluidity and macromolecular structural integrity in proteins and ribosomes $[21,22]$ and synthesize cold shock proteins [23]. Starvation stress causes an increase in cellular resistance capability by means of the use of alternative growth substrates or energy 

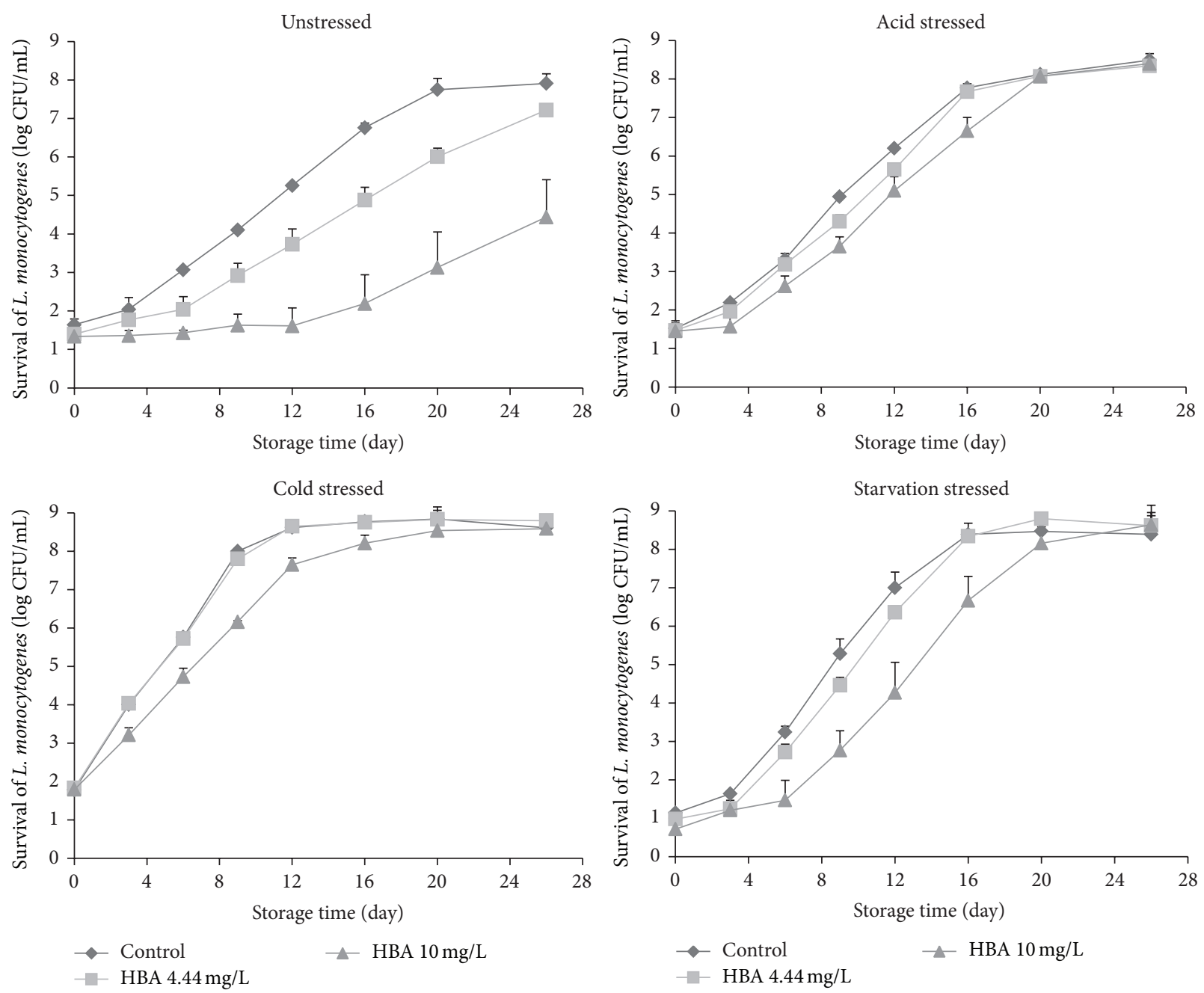

FIGURE 1: Means (SD, log CFU/mL) of unstressed and acid-, cold-, and starvation-stressed L. monocytogenes (tryptic soy agar with $0.6 \%$ yeast extract) populations in ham extract containing 0.0 (control), 4.44, and $10.0 \mathrm{mg} / \mathrm{L}$ hops beta acids (HBA) during storage at $7.2^{\circ} \mathrm{C}$ for 26 days.

to stabilize ribosomes against degradation [24], change morphological transformation into spherical conformations [25], and enhance metabolic potential of microorganisms [26]. It is reported that starvation proteins are encoded by two groups of genes, including cst genes controlled by carbon starvation and pex genes controlled by carbon, nitrogen, or phosphorus starvation [26].

3.2. Data Modeling. In a preliminary study, four reduced and four full growth models in the USDA-IPMP software were used to evaluate the fitness of the model to predict the growth kinetics of cells in different treatments (i.e., low value of RMSE and AIC). As shown in Table 1, the Baranyi Full Growth Model fitted well growth data for all treatments based on their low RMSE (from 0.152 to 0.524 ) and low AIC scores (from -12.545 to -99.284). Therefore, the DMFIT software, based on Baranyi Full Growth Model, was used to compare the lag phase periods and growth rates in all treatments (Table 2).
For unstressed L. monocytogenes cells, reduced growth rates of 0.29 and $0.24 \log \mathrm{CFU} / \mathrm{mL} /$ day were obtained in 4.44 and $10.0 \mathrm{mg} / \mathrm{L} \mathrm{HBA-treated} \mathrm{ham} \mathrm{extract} \mathrm{(Table} \mathrm{2),} \mathrm{respec-}$ tively, which were lower $(P<0.05)$ than in ham extracts without HBA (control, growth rates of $0.39 \log \mathrm{CFU} / \mathrm{mL} /$ day, Table 2). Corresponding to the microbiological data (Figures 1 and 2), HBA treatments extended the lag phase time from 2.49 days in controls to $3.49(P>0.05)$ and to 12.98 days $(P<0.05)$ in 4.44 and $10.0 \mathrm{mg} / \mathrm{L} \mathrm{HBA}$ treatments, respectively (Table 2 ). These findings verified that HBA had promising bacteriostatic effects for unstressed $L$. monocytogenes cells in ham extract.

In the absence of HBA, the three types of stress-adapted cells behaved differently $(P<0.05)$ during storage with the calculated growth rates increasing as 0.39 (unstressed) < 0.50 (acid) $<0.68$ (starvation) $\leq 0.71$ (cold) $\log \mathrm{CFU} / \mathrm{mL} /$ day and lag phase periods decreasing as 3.26 (starvation) $\geq 2.49$ (unstressed) $\geq 2.33$ (acid) > undetected (cold) (Table 2). The longer lag phase time shown in starvation-stressed 


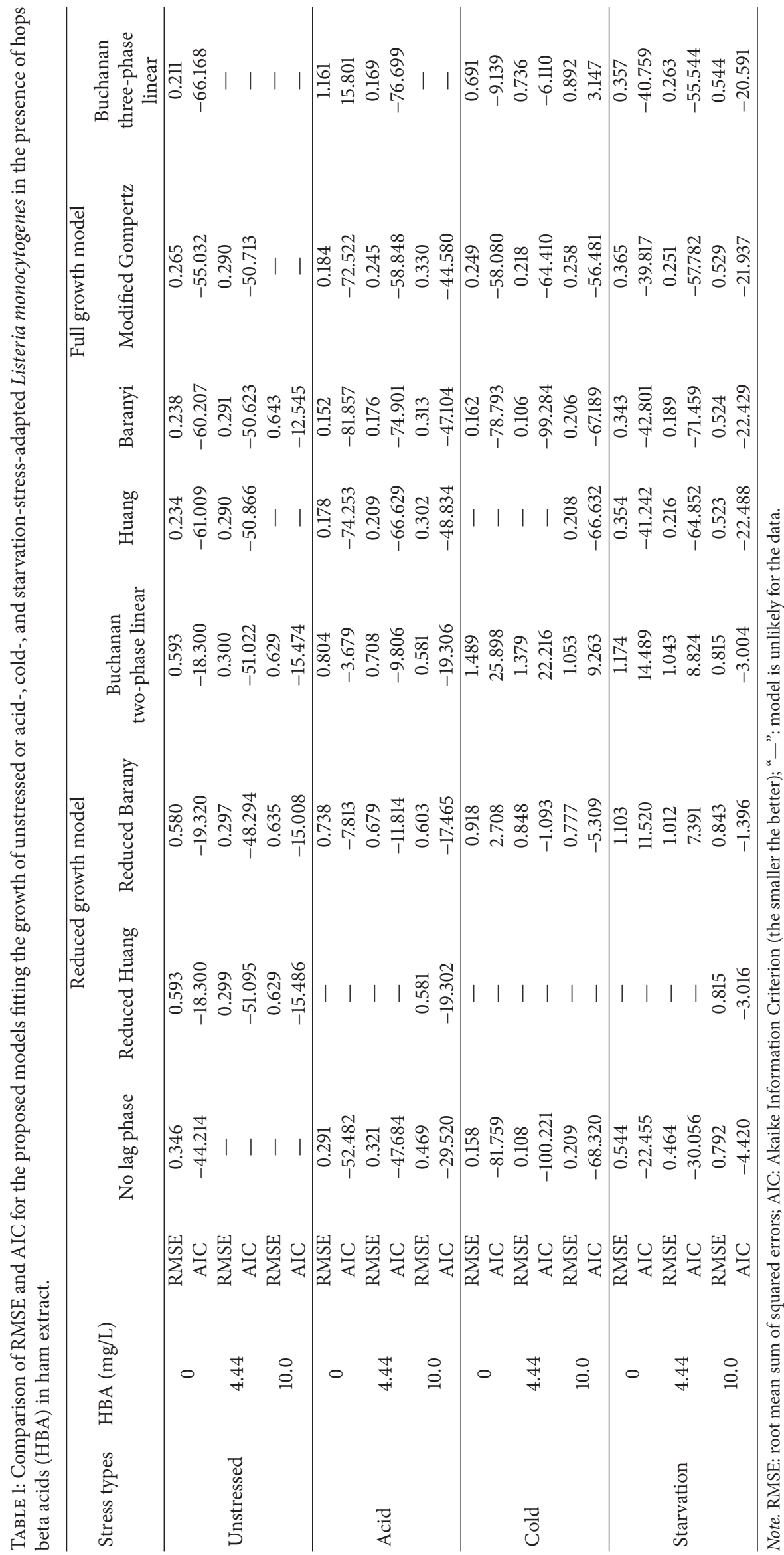



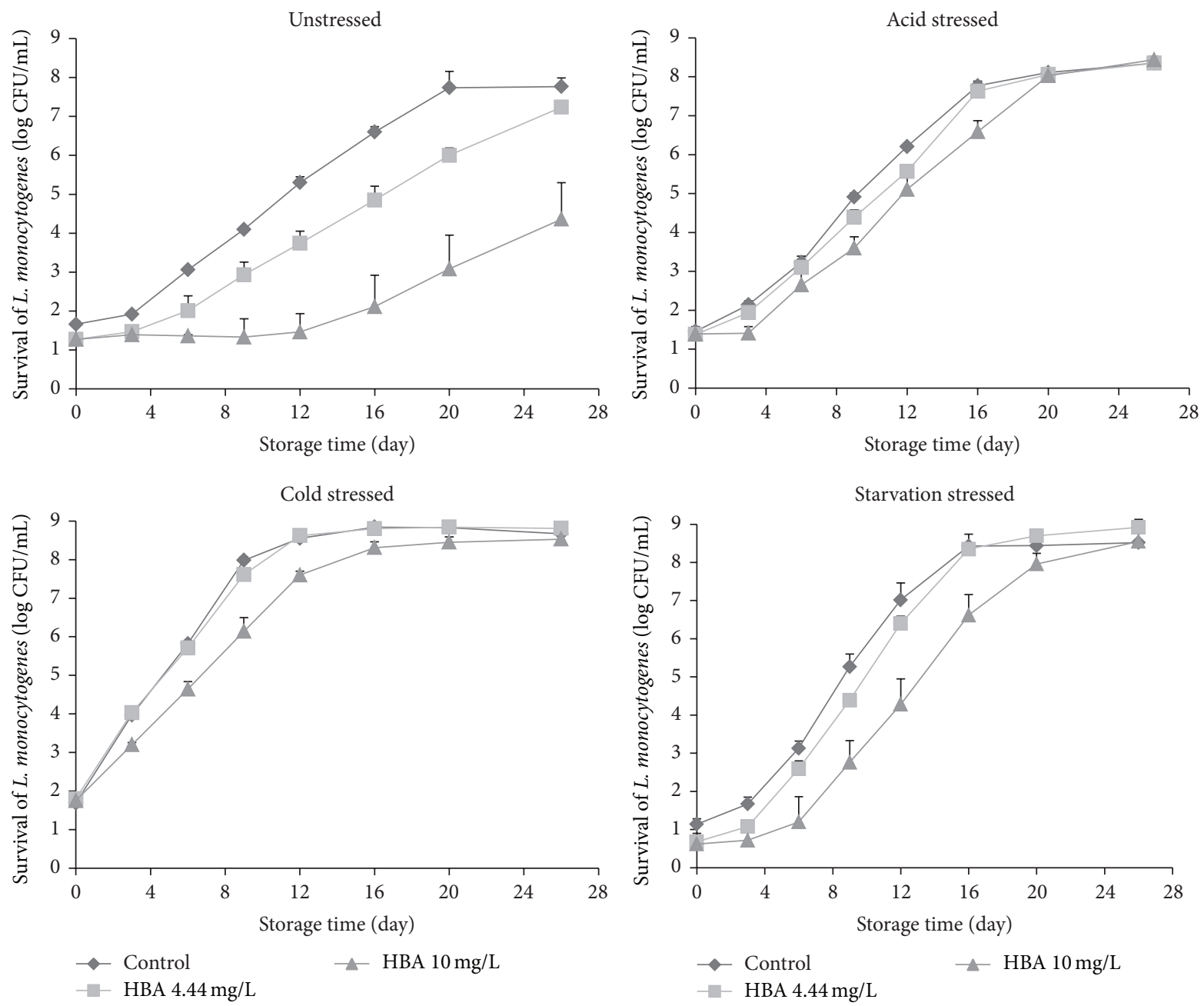

Figure 2: Means (SD, $\log \mathrm{CFU} / \mathrm{mL}$ ) of unstressed and acid-, cold-, and starvation-stressed L. monocytogenes (PALCAM agar) populations in ham extract containing 0.0 (control), 4.44, and $10.0 \mathrm{mg} / \mathrm{L}$ hops beta acids (HBA) during storage at $7.2^{\circ} \mathrm{C}$ for 26 days.

TABLE 2: Means (S.E.) of lag phase duration (LPD) and growth rate (GR) of unstressed and acid-, cold-, and starvation-stress-adapted L. monocytogenes during exposure to hops beta acids (HBA) in ham extract calculated using the Baranyi Full Growth Model in DMFIT software.

\begin{tabular}{|c|c|c|c|c|}
\hline Type of stress & $\begin{array}{c}\text { HBA } \\
\text { concentration }\end{array}$ & $\begin{array}{c}\text { LPD } \\
\text { (days) }\end{array}$ & $\begin{array}{c}\mathrm{GR} \\
(\log \mathrm{CFU} / \mathrm{ml} / \text { day })\end{array}$ & $R^{2}$ \\
\hline \multirow{3}{*}{ Unstressed } & $0.0 \mathrm{mg} / \mathrm{L}$ (control) & $2.49^{\mathrm{a}}(0.79)$ & $0.39^{\mathrm{a}}(0.03)$ & 0.99 \\
\hline & $4.44 \mathrm{mg} / \mathrm{L}$ & $3.49^{\mathrm{a}}(1.30)$ & $0.29^{\mathrm{b}}(0.03)$ & 0.98 \\
\hline & $10.0 \mathrm{mg} / \mathrm{L}$ & $12.98^{\mathrm{b}}(3.14)$ & $0.24^{\mathrm{b}}(0.07)$ & 0.93 \\
\hline \multirow{3}{*}{ Acid } & $0.0 \mathrm{mg} / \mathrm{L}$ (control) & $2.33^{\mathrm{a}}(0.46)$ & $0.50^{\mathrm{c}}(0.02)$ & 0.99 \\
\hline & $4.44 \mathrm{mg} / \mathrm{L}$ & $2.89^{\mathrm{a}}(0.46)$ & $0.48^{\mathrm{c}}(0.02)$ & 0.99 \\
\hline & $10.0 \mathrm{mg} / \mathrm{L}$ & $3.42^{\mathrm{a}}(0.88)$ & $0.44^{\mathrm{c}}(0.03)$ & 0.99 \\
\hline \multirow{3}{*}{ Cold } & $0.0 \mathrm{mg} / \mathrm{L}$ (control) & - & $0.71^{\mathrm{d}}(0.02)$ & 0.99 \\
\hline & $4.44 \mathrm{mg} / \mathrm{L}$ & - & $0.65^{\mathrm{d}}(0.01)$ & 0.99 \\
\hline & $10.0 \mathrm{mg} / \mathrm{L}$ & - & $0.50^{\mathrm{c}}(0.01)$ & 0.99 \\
\hline \multirow{3}{*}{ Starvation } & $0.0 \mathrm{mg} / \mathrm{L}$ (control) & $3.26^{\mathrm{a}}(0.73)$ & $0.68^{\mathrm{d}}(0.07)$ & 0.99 \\
\hline & $4.44 \mathrm{mg} / \mathrm{L} \mathrm{HBA}$ & $3.30^{\mathrm{a}}(0.40)$ & $0.66^{\mathrm{d}}(0.03)$ & 0.99 \\
\hline & $10.0 \mathrm{mg} / \mathrm{L} \mathrm{HBA}$ & $5.44^{\mathrm{a}}(1.13)$ & $0.57^{\mathcal{C}}(0.07)$ & 0.97 \\
\hline
\end{tabular}

-: Lag phase duration is not detected.

${ }^{\mathrm{a}-\mathrm{d}}$ Means in the same column with the same superscript letter were not significantly different $(P>0.05)$. 
TABLE 3: Sensory analysis of ready-to-eat (RTE) ham treated with hops beta acids (HBA) solution.

\begin{tabular}{lcccccc}
\hline Treatment $^{\mathrm{a}}$ & Appearance $^{\mathrm{b}}$ & Color $^{\mathrm{c}}$ & Odor $^{\mathrm{b}}$ & Flavor $^{\mathrm{b}}$ & Texture $^{\mathrm{d}}$ & Overall acceptability $^{\mathrm{b}}$ \\
\hline Control & $6.25 \pm 0.66^{\mathrm{a}}$ & $5.94 \pm 1.03^{\mathrm{a}}$ & $5.68 \pm 1.02^{\mathrm{a}}$ & $6.28 \pm 1.28^{\mathrm{a}}$ & $5.73 \pm 1.37^{\mathrm{a}}$ & $6.20 \pm 1.12^{\mathrm{a}}$ \\
DW & $5.99 \pm 0.71^{\mathrm{ab}}$ & $5.21 \pm 0.86^{\mathrm{a}}$ & $5.26 \pm 0.89^{\mathrm{ab}}$ & $5.66 \pm 1.39^{\mathrm{a}}$ & $5.10 \pm 0.80^{\mathrm{a}}$ & $6.14 \pm 0.93^{\mathrm{a}}$ \\
$0.05 \%$ HBA & $5.90 \pm 0.58^{\mathrm{ab}}$ & $5.11 \pm 0.78^{\mathrm{a}}$ & $5.33 \pm 0.84^{\mathrm{ab}}$ & $5.46 \pm 1.13^{\mathrm{a}}$ & $6.01 \pm 0.82^{\mathrm{a}}$ & $5.64 \pm 1.36^{\mathrm{a}}$ \\
$0.11 \%$ HBA & $6.03 \pm 0.82^{\mathrm{ab}}$ & $5.19 \pm 0.56^{\mathrm{a}}$ & $5.14 \pm 0.67^{\mathrm{ab}}$ & $5.48 \pm 1.15^{\mathrm{a}}$ & $6.06 \pm 0.80^{\mathrm{a}}$ & $5.86 \pm 0.86^{\mathrm{a}}$ \\
$0.23 \%$ HBA & $5.24 \pm 0.77^{\mathrm{b}}$ & $4.85 \pm 0.85^{\mathrm{a}}$ & $4.71 \pm 0.57^{\mathrm{b}}$ & $4.58 \pm 0.92^{\mathrm{a}}$ & $5.33 \pm 0.80^{\mathrm{a}}$ & $4.51 \pm 1.01^{\mathrm{a}}$ \\
\hline
\end{tabular}

${ }^{a}$ Means with the same letter were not significantly different $(P>0.05)$.

$\mathrm{b}_{1}=$ dislike extremely; 9 = like extremely.

${ }^{c} 1=$ extremely pale; $9=$ extremely dark.

$\mathrm{d}_{1}=$ extremely soft; $9=$ extremely firm.

cells can be explained by the "shift-up" effect [27]. After transferring L. monocytogenes cells from $0.85 \%$ salt solution (starvation stress) to the ham extract, the cells needed extra time to construct new ribosome to enhance their ability for protein synthesis, resulting in a longer lag phase time [27]. Overall, after exposure to HBA, compared to the unstressed L. monocytogenes cells, acid-, cold- or starvationstress-adapted pathogen cells showed higher $(P<0.05)$ growth rates, indicating cross protection effects. Specifically, among the 4.44 and $10.0 \mathrm{mg} / \mathrm{L}$ HBA treatments, the growth rates increased as 0.24 to 0.29 (unstressed) $<0.44$ to 0.48 (acid) $<0.50$ to 0.65 (cold) $\leq 0.57$ to 0.66 (starvation) $\log$ $\mathrm{CFU} / \mathrm{mL} /$ day (Table 2). The lag phase periods were similar $(P>0.05)$ in most HBA treatments regardless of various types of stress (Table 2). There was an inhibitory function of HBA on stress-adapted cells, especially for $10.0 \mathrm{mg} / \mathrm{L} \mathrm{HBA}$. For example, the growth rates of $10.0 \mathrm{mg} / \mathrm{L}$ HBA-treated coldand starvation-stressed cells ( 0.50 and $0.57 \log \mathrm{CFU} / \mathrm{mL} /$ day) were significantly lower than those from the control and $4.0 \mathrm{mg} / \mathrm{L}$ HBA treatment.

3.3. $p H$ Variation of Ham Extract. The average initial $\mathrm{pH}$ of untreated ham extract solution on day 0 was 6.16 , while after adding HBA, the pH slightly increased to 6.21 to 6.24 (Figure 3), which is in agreement with the previous study [14]. As expected, the $\mathrm{pH}$ of the ham extract solution during 26 days of storage decreased significantly in samples in which significant growth $(>6-7 \log \mathrm{CFU} / \mathrm{mL})$ of the unstressed or stress-adapted $L$. monocytogenes occurred in ham extract solution. The $\mathrm{pH}$ decrease was attributed to the microbial metabolism of carbohydrates of ham extract, generating acid into ham extract solutions in which significant growth of the pathogen population was observed [18]. For unstressed pathogen cells, the $\mathrm{pH}$ of HBA-treated samples did not change significantly $(P \geq 0.05)$ until 20 to 26 days of storage (Figure 3 ), suggesting that the unstressed L. monocytogenes did not grow rapidly in the presence of HBA. However, a dramatic decrease of $\mathrm{pH}$ value occurred at days 16 to 20,9 to 16 , and 16 for acid-, cold-, and starvation-stress-adaptedcells, respectively, regardless of control or HBA treatments (Figure 3), indicating rapid pathogen growth due to their resistance to HBA.
3.4. Sensory Evaluation. In an early study reported by Shen et al. [15], dipping frankfurters into 0.06 to $0.10 \% \mathrm{HBA}$ solutions inhibited L. monocytogenes for 30 to 50 days of vacuum sealed storage at 4 or $10^{\circ} \mathrm{C}$; however, it raised the concern that applying HBA on RTE meats might cause adverse sensory effects. Therefore, in this study, sensory evaluation was performed on unheated RTE hams dipped into 0.05 to $0.23 \%$ HBA followed by 24 -h vacuum package storage at $4^{\circ} \mathrm{C}$. The 30 participating panelists were primarily university food science graduate students (90\%) with the age from 21 to 30 years $(82 \%), 55 \%$ of whom were male. More than half of the participants $(65 \%)$ indicated that they liked to eat RTE deli meats and frankfurters, and $50 \%$ and $45 \%$ of them ate RTE meats one to three times per month and one to five times per year, respectively. The slightly greater standard deviations that ranged from 0.56 to 1.39 (Table 3 ) were expected in this study, because an untrained consumer style panel was used to perform the sensory evaluation analysis.

The average hedonic scores of untreated ham were 5.686.28 across items of appearance, color, odor, flavor, texture, and overall acceptability (Table 3 ). After dipping into distilled water or 0.05 or $0.11 \% \mathrm{HBA}$, slightly $(P>0.05)$ lower scores were obtained among 30 panel members compared to those obtained from the untreated samples. In general, immersing ham in 0.05 and $0.11 \%$ HBA did not cause any negative effects on the tested sensory attributes, ranking between "neither like nor dislike" and "like slightly" (Table 3). Color scores were only slightly lower $(P>0.05)$, from 5.11 to 5.19 , in 0.05 and $0.11 \%$ HBA-dipped hams; thus HBA did not bring severe brownish color to the ham surfaces. However, the lowest mean hedonic scores of all sensory attributes were seen in the $0.23 \%$ HBA-treated samples (Table 3 ). HBA is derived from hops flowers used for beer brewing process and therefore has the potential to impart a "beer like" bitter taste. Adding too much HBA into postlethality dipping solutions may decrease sensory acceptability of treated RTE meat products. In a previous study, Geornaras et al. [28] found that commercial ham and frankfurters treated with organic acids such as lactic and acetic acids resulted in significant lower hedonic scores compared to untreated controls. In this study, 0.05 and $0.11 \%$ HBA-treated samples had only slightly lower sensory scores in all attributes. Therefore, it is suggested that HBA did not cause extra adverse sensory effects as compared to the other 

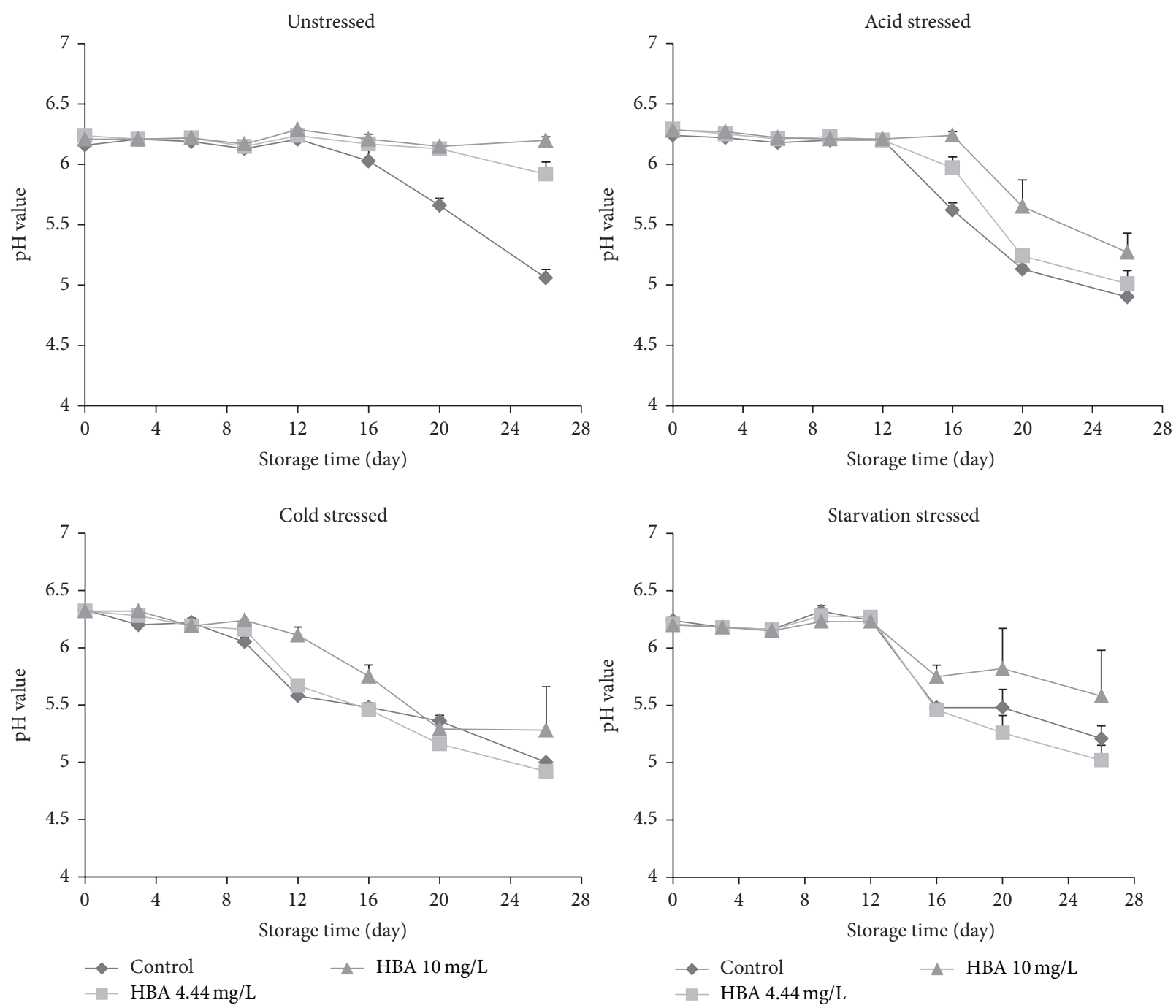

Figure 3: Mean (SD) pH values of ham extract containing 0.0 (control), 4.44, and $10.0 \mathrm{mg} / \mathrm{L}$ hops beta acids (HBA) during storage at $7.2^{\circ} \mathrm{C}$ for 26 days.

widely used organic acid base antimicrobials. Thus, $0.11 \%$ HBA, which generated a residual concentration of $4.44 \mathrm{mg} / \mathrm{kg}$ HBA on the RTE meat surfaces (recommended by USDAFSIS), should be confidently applied during postlethality RTE meat processing.

\section{Conclusion}

Results of the present study indicated that HBA exhibited promising inhibitory effects for unstressed L. monocytogenes in ham extract stored at $7.2^{\circ} \mathrm{C}$. The sensory evaluation results confirmed that applying $4.4 \mathrm{mg} / \mathrm{kg}$ of HBA on RTE hams (approved by USDA-FSIS and US-FDA) will not cause adverse sensory effects. However, acid-, cold-, and starvationstress-adapted L. monocytogenes cells showed resistance and cross protection to HBA. For industrial RTE meat processers, challenge studies should examine whether meat decontamination with organic acids or cold storage may provide cross protection of L. monocytogenes to subsequent exposure to antimicrobials, such as HBA, during postlethality processing of RTE meats. Future studies are needed to evaluate the antilisterial activities of HBA on more RTE products such as uncured or cured ham, turkey breast, and roast beef.

\section{Conflict of Interests}

The authors declare that there is no conflict of interests regarding the publication of this paper.

\section{Acknowledgments}

This work was supported by Jiangsu province science and technology support program (BE2012404) and international research collaboration between Jiang Nan University, China, and West Virginia University, USA. The authors appreciate S.S. Steiner Inc., New York, NY, USA, for their donation of the hops beta acids product. They appreciate Dr. Keith 
Inskeep, professor at West Virginia University, USA, who did the critical English proofreading for this paper.

\section{References}

[1] J. M. Jay, M. J. Loessner, and D. A. Golden, "Foodborne listeriosis," in Modern Food Microbiology, J. M. Jay, M. J. Loessner, and D. A. Golden, Eds., pp. 591-617, Springer Science Business Media, New York, NY, USA, 2005.

[2] B. H. Lado and A. E. Yousef, "Characteristics of Listeria monocytogenes important to food processors," in Listeria, Listeriosis, and Food Safety, E. T. Ryser and E. H. March, Eds., pp. 157-213, CRC Press, Boca Raton, Fla, USA, 2007.

[3] E. T. Ryser and E. H. Marth, Listeria, Listeriosis and Food Safety, Marcel Dekker, New York, NY, USA, 2nd edition, 1999.

[4] CDC (Centers for Disease Control and Prevention), "Multistate outbreak of listeriosis, United States," Morbidity and Mortality Weekly Report, vol. 47, no. 50, pp. 1085-1086, 1998.

[5] Centers for Disease Control and Prevention, "Update: multistate outbreak of listeriosis, United States, 1998-1999," Morbidity and Mortality Weekly Report, vol. 47, no. 51, pp. 1117-1118, 1998.

[6] CDC and Centers for Disease Control and Prevention, "Multistate outbreak of listeriosis, United States, 2000," Morbidity and Mortality Weekly Report, vol. 49, no. 50, pp. 1129-1130, 2000.

[7] CDC (Centers for Disease Control and Prevention), "Public health dispatch: outbreak of listeriosis, Northeastern United States, 2002," Morbidity and Mortality Weekly Report, vol. 51, no. 42, pp. 950-951, 2002.

[8] USDA-FSIS, "Control of Listeria monocytogenes in ready-toeat-meat and poultry products; final rule," Federal Register, vol. 52, p. 7464, 2003.

[9] USDA-FSIS (U.S. Department of Agriculture Food Safety and Inspection Service), FSIS Compliance Guideline: Controlling Listeria monocytogenes in Post-Lethality Exposed Readyto-Eat Meat and Poultry Products, 2014, http://www .fsis.usda.gov/wps/wcm/connect/d3373299-50e6-47d6-a577 -e74ale549fde/Controlling-Lm-RTE-Guideline.pdf?MOD= AJPERES.

[10] T. Abee and J. A. Wouters, "Microbial stress response in minimal processing," International Journal of Food Microbiology, vol. 50, no. 1-2, pp. 65-91, 1999.

[11] J. Samelis and J. N. Sofos, "Strategies to control stress-adapted pathogen," in Microbial Stress Adaptation and Food Safety, A. E. Yousef and V. K. Juneja, Eds., pp. 303-353, CRC Press, New York, NY, USA, 2003.

[12] US-FDA, "U. S. Food and Drug Administration," Center for Food Safety \& Applied Nutrition Office of Premarket Approval, GRAS Notice No. GRN 000063, 2001, http://www.accessdata .fda.gov/scripts/fcn/gras_notices/grn0063.pdf.

[13] USDA-FSIS, Safe and Suitable Ingredients Used in the Production of Meat and Poultry Products, US Department of Agriculture Food Safety and Inspection Service, 2008, http://www.fsis.usda .gov/OPPDE/rdad/FSISDirectives/7120.1Amend14.pdf.

[14] C. Shen and J. N. Sofos, "Antilisterial activity of hops beta acids in broth with or without other antimicrobials," Journal of Food Science, vol. 73, no. 9, pp. M438-M442, 2008.

[15] C. Shen, I. Geornaras, P. A. Kendall, and J. N. Sofos, "Control of listeria monocytogenes on frankfurters by dipping in hops beta acids solutions," Journal of Food Protection, vol. 72, no. 4, pp. 702-706, 2009.
[16] C. Shen, I. Geornaras, K. E. Belk, G. C. Smith, and J. N. Sofos, "Thermal inactivation of acid, cold, heat, starvation, and desiccation stress-adapted Escherichia coli O157:H7 in moisture-enhanced nonintact beef," Journal of Food Protection, vol. 74, no. 4, pp. 531-538, 2011.

[17] L. Huang, "IPMP 2013-a comprehensive data analysis tool for predictive microbiology," International Journal of Food Microbiology, vol. 171, pp. 100-107, 2014.

[18] I. Geornaras, Y. Yoon, K. E. Belk, G. C. Smith, and J. N. Sofos, "Antimicrobial activity of $\varepsilon$-polylysine against Escherichia coli O157:H7, Salmonella typhimurium, and Listeria monocytogenes in various food extracts," Journal of Food Science, vol. 72, no. 8, pp. M330-M334, 2007.

[19] M. Teuber and A. F. Schmalreck, "Membrane leakage in Bacillus subtilis 168 induced by the hop constituents lupulone, humulone, isohumulone and humulinic acid," Archives of Microbiology, vol. 94, no. 2, pp. 159-171, 1973.

[20] J. L. Slonczewski and J. W. Foster, "pH-regulated genes and survival at extreme $\mathrm{pH}$," in Escherichia Coli and Salmonella Typhimurium: Cellular and Molecular Biology, F. C. Neidhardt, Ed., pp. 1539-1549, ASM Press, Washington, DC, USA, 1996.

[21] R. Jaenicke, "Protein stability and molecular adaptation to extreme conditions," European Journal of Biochemistry, vol. 202, no. 3, pp. 715-728, 1991.

[22] E. D. Berry and P. M. Foegeding, "Cold temperature adaptation and growth of microorganisms," Journal of Food Protection, vol. 60, no. 12, pp. 1583-1594, 1997.

[23] W. Jiang, Y. Hou, and M. Inouye, "CspA, the major cold-shock protein of Escherichia coli, is an RNA chaperone," The Journal of Biological Chemistry, vol. 272, no. 1, pp. 196-202, 1997.

[24] T. Tolker-Nielsen and S. Molin, "Role of ribosome degradation in the death of heat-stressed Salmonella typhimurium," FEMS Microbiology Letters, vol. 142, no. 2-3, pp. 155-160, 1996.

[25] M. Givskov, L. Eberl, S. Møller, L. K. Poulsen, and S. Molin, "Responses to nutrient starvation in Pseudomonas putida KT2442: analysis of general cross-protection, cell shape, and macromolecular content," Journal of Bacteriology, vol. 176, no. 1, pp. 7-14, 1994.

[26] A. Matin, "The molecular basis of carbon-starvation-induced general resistance in Escherichia coli," Molecular Microbiology, vol. 5, no. 1, pp. 3-10, 1991.

[27] J. M. Willey, L. M. Sherwood, and C. J. Woolverton, "Microbial growth," in Prescott's Microbiology, J. M. Willey, L. M. Sherwood, and C. J. Woolverton, Eds., chapter 7, pp. 155-189, McGraw-Hill, New York, NY, USA, 2009.

[28] I. Geornaras, K. E. Belk, J. A. Scanga, P. A. Kendall, G. C. Smith, and J. N. Sofos, "Postprocessing antimicrobial treatments to control Listeria monocytogenes in commercial vacuumpackaged Bologna and ham stored at $10^{\circ} \mathrm{C}$," Journal of Food Protection, vol. 68, no. 5, pp. 991-998, 2005. 

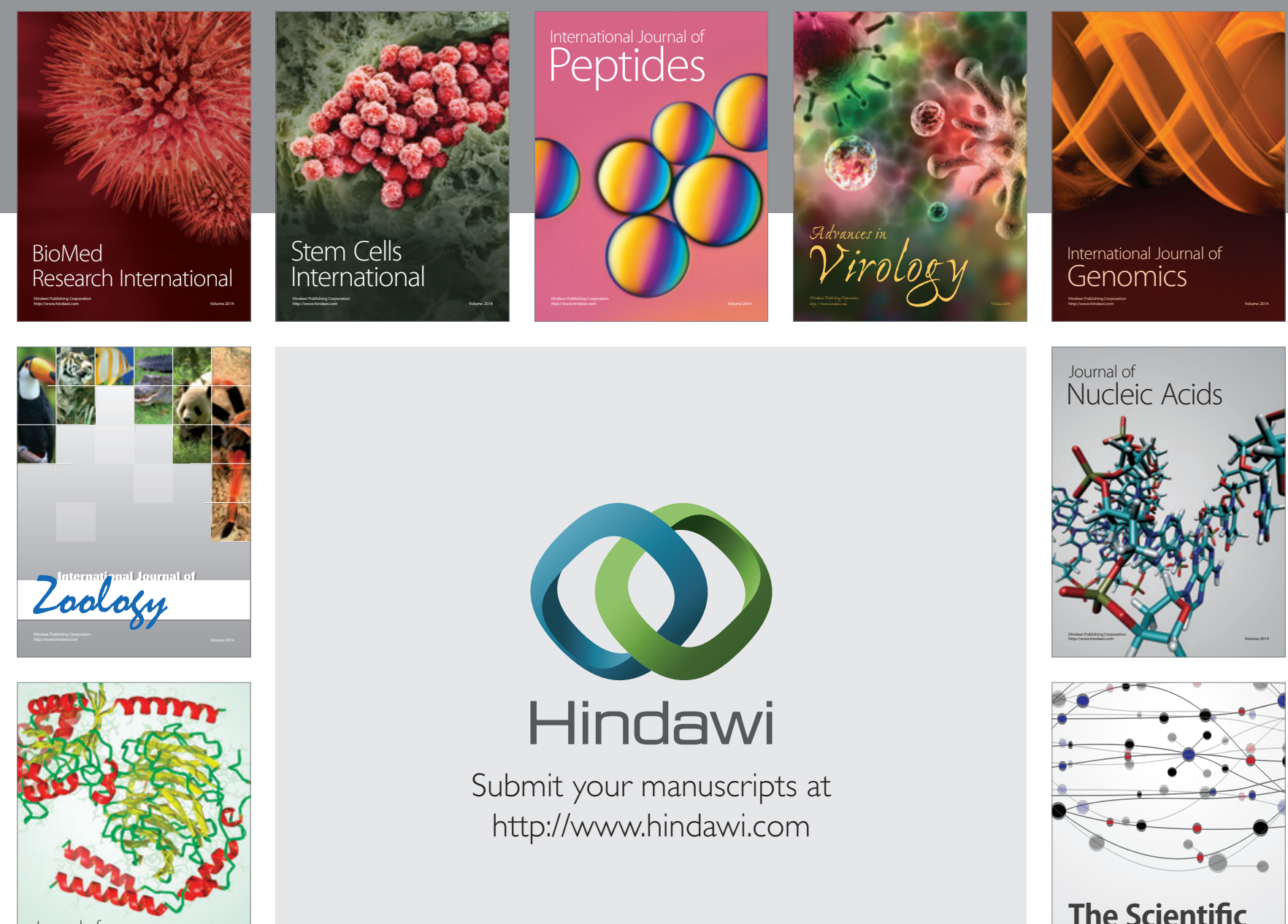

Submit your manuscripts at

http://www.hindawi.com

Journal of
Signal Transduction
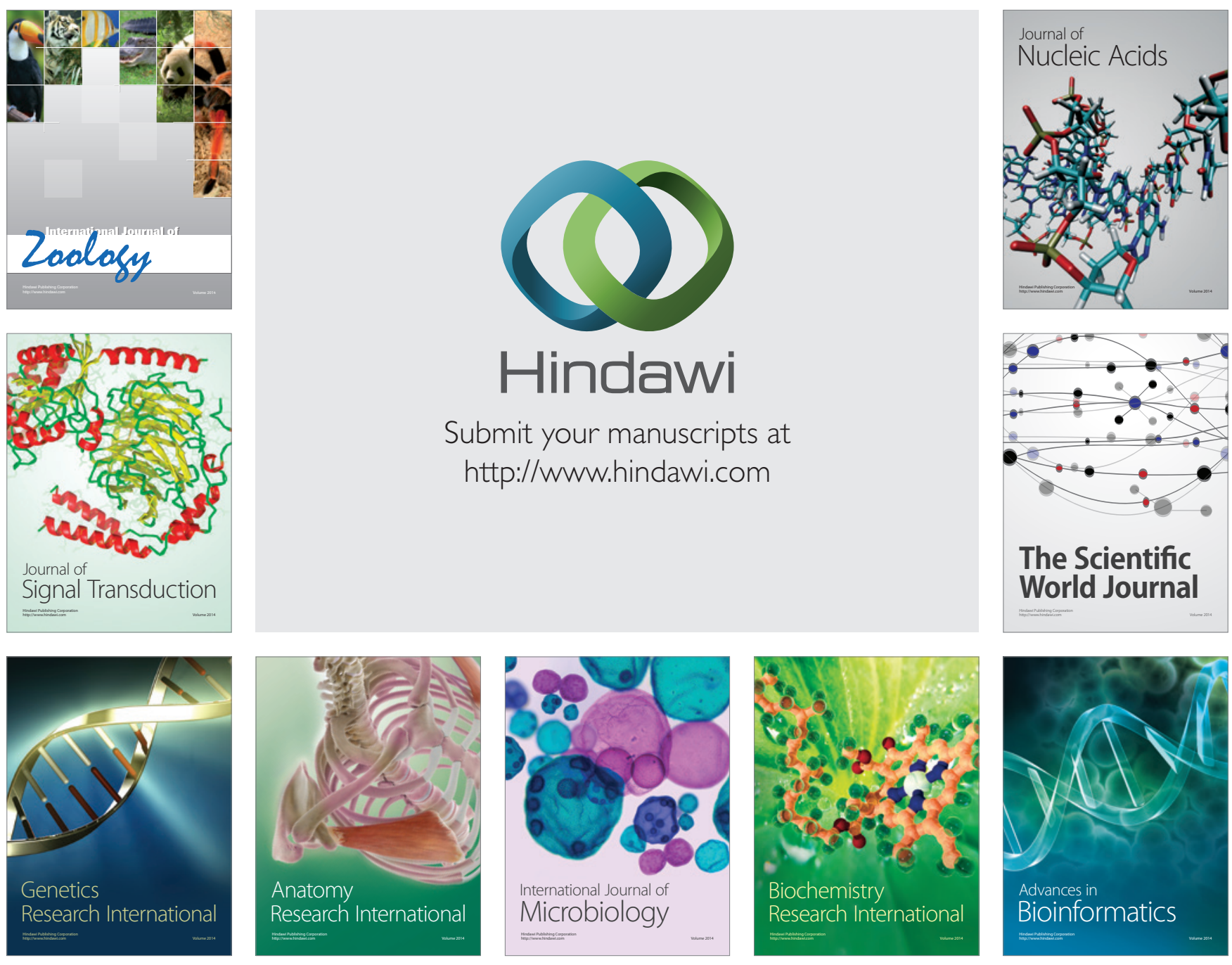

The Scientific World Journal
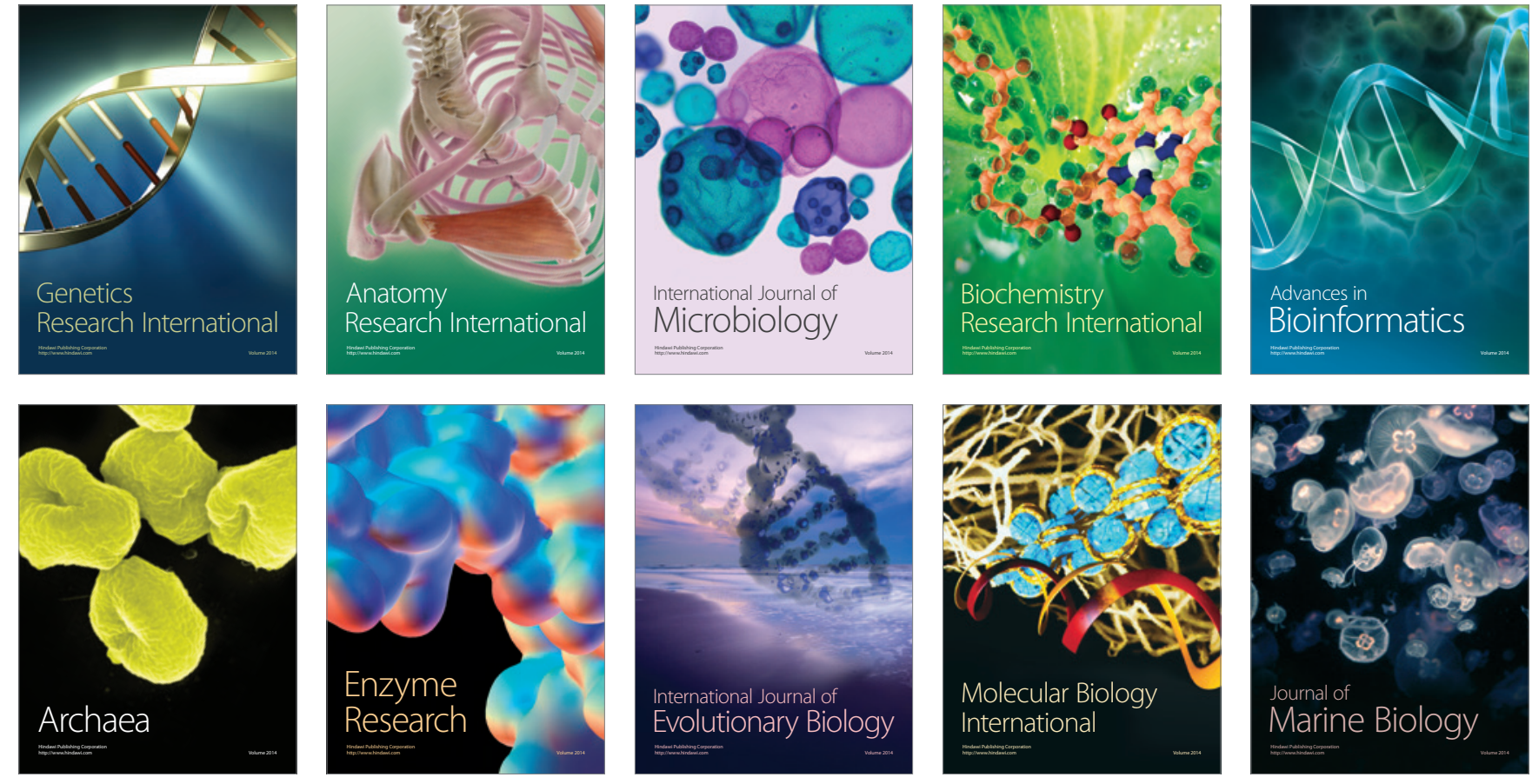